University of Michigan Law School

University of Michigan Law School Scholarship Repository

Articles

Faculty Scholarship

1998

\title{
Physician-Assisted Suicide: The Problems Presented by the Compelling, Heartwrenching Case
}

Yale Kamisar

University of Michigan Law School, ykamisar@umich.edu

Available at: https://repository.law.umich.edu/articles/273

Follow this and additional works at: https://repository.law.umich.edu/articles

Part of the Constitutional Law Commons, Medical Jurisprudence Commons, State and Local Government Law Commons, and the Supreme Court of the United States Commons

\section{Recommended Citation}

Kamisar, Yale. "Physician-Assisted Suicide: The Problems Presented by the Compelling, Heartwrenching Case." J. Crim. L. \& Criminology 88, no. 3 (1998): 1121-46.

This Article is brought to you for free and open access by the Faculty Scholarship at University of Michigan Law School Scholarship Repository. It has been accepted for inclusion in Articles by an authorized administrator of University of Michigan Law School Scholarship Repository. For more information, please contact mlaw.repository@umich.edu. 


\section{POPE \& JOHN LECTURE ON PROFESSIONALISM}

In 1991, the Chicago law firm of Pope $\mathcal{E}^{2} J o h n$ Ltd. established a lecture series at Northwestern University School of Law. The Pope Ev John Lecture on Professionalism focuses on the many dimensions of a lawyer's professional responsibility, including legal ethics, public service, professional civility, pro bono representation, and standards of conduct. The Joumal of Criminal Law E Criminology presents the October 25, 1997 Pope $\mathcal{E}$ John Lecture by Professor Yale Kamisar, which is followed by three responding commentaries.

\section{PHYSICIAN-ASSISTED SUICIDE: THE PROBLEMS PRESENTED BY THE COMPELIING, HEARTWRENGHING CASE}

\section{YALE KAMISAR*}

\section{INTRODUCTION}

On the question you ask depends the answer you get. ${ }^{1}$

Now that the U.S. Supreme Court has upheld New York and Washington state laws prohibiting the aiding of another to commit suicide, ${ }^{2}$ the spotlight will shift to the state courts, the School.

- Clarence Darrow Distinguished University Professor, University of Michigan Law

'Bay Ridge Operating Co. v. Aaron, 334 U.S. 446, 484 (1948) (Frankfurter, J., dissenting). See also HENRY J. FRIENDLY, Mr. Justice Frankfurter, in BENCHMARKS 318-19 (1967).

${ }^{2}$ Washington v. Glucksberg, 117 S. Ct. 2258 (1997); Vacco v. Quill, 117 S. Ct. 2293 (1997). See generally Symposium, Physician-Assisted Suicide: Facing Death After Glucksberg and Quill, 82 MINN. L. REv. 885 (1998); Brett Feinberg, Note, The Court Upholds A State Law Prohibiting Physician-Assisted Suicide, 88 J. CRIM. L. \& CRIMINOLOGY 847 (1998) (this issue). 
state legislatures and state referenda. And once again proponents of physician-assisted suicide (PAS) will point to a heartwrenching case, perhaps the relatively rare case where a dying person is experiencing unavoidable pain (i.e., pain that not even the most skilled palliative care experts are able to mitigate), and ask: What would you want done to you if you were in this person's shoes?

That is a hard question for opponents of PAS to answer, but, as I shall try to spell out in this article, I think it is the wrong question to ask. To put it another way, I think it is a very different question than one which asks: Should we enact a law allowing PAS under certain circumstances?

Different people oppose the legalization of PAS (or physician administered active voluntary euthanasia) for different reasons. I believe that what John Arras said of the twenty-four persons who made up the New York State Task Force on Life and the Law (New York Task Force)-all of whom wound up opposing the legalization of PAS/euthanasia ${ }^{3}$ - applies to opponents of PAS/euthanasia generally. As Professor Arras pointed out, the opponents fall into three major camps:

First, those who believe the practices are "inherently immoral." Second, those who are greatly disturbed by the fact that "physicians are being called upon to do the killing," a development they view as "fatally compromis[ing] the physicianpatient relationship." Third, those who recognize that in certain rare instances PAS/euthanasia might constitute "a positive good," but nevertheless "shrink from endorsing" these practices because they fear the "social consequences" of legalization. ${ }^{6}$

Professor Arras has disclosed that during his tenure with the New York Task Force he belonged to the third faction. ${ }^{7}$ So do $\mathrm{I}^{8}$

3 See The New York State Task Force on LIFE ANd the Law, When Death Is SOUGHT: Assisted SuICIdE AND EUtHANASIA IN THE MEdical CONTEXT (May 1994) [hereinafter NEW YORK TASK FORCE REPORT].

'John D. Arras, Physician-Assisted Suicide: A Tragic View, 13 J. CONTEMP. HEALTH L. \& POL'Y 361, 367-68 (1997).

${ }^{5} I d$ at 368 .

${ }^{6} I d$.

${ }^{7} I d$ at 368 n.26.

${ }^{8}$ See Yale Kamisar, Some Non-Religious Views Against Proposed "Mercy-Killing" Legislation, 42 MrNN. L. REv. 969, 975-77 (1958). 
For those of us whose opposition to the legalization of PAS/euthanasia is based on grounds that put us in the third camp, the heartwrenching case, e.g., a person enduring the last stages of ALS (Lou Gehrig's disease) who, barely able to speak, begs for immediate death, is especially troublesome. Indeed, the heartwrenching case is a principal reason why there is so much support for PAS/euthanasia in this country.

All too often a reporter believes that the way to provide an in-depth treatment of the subject is to set forth a detailed account of $a$ particular. individual begging for assistance in committing suicide-a detailed, poignant account that blots out what might be called societal or public policy considerations. And all too often, I suspect, when asked by pollsters about their views on the issue, people focus on the compelling case for PAS/euthanasia they have read or heard about-with nary a thought about the societal consequences of legalizing the practice.

As Professor Arras has pointed out, whether we maintain the total prohibition against PAS/euthanasia or whether we lift the ban for certain groups of people, "there are bound to be 'victims." "' Continues Arras:

The victims of the current policy are easy to identify: they are on the news, the talk shows, the documentaries, and often on Dr. Kevorkian's roster of so-called "patients." The victims of legalization, by contrast, will be largely hidden from view; they will include the clinically depressed eighty-year-old man who could have lived for another year of quality if only he had been adequately treated, and the fifty-year-old woman who asks for death because doctors in her financially stretched HMO cannot, or will not, effectively treat her unrelenting, but mysterious pelvic pain .. 10

${ }^{9}$ Arras, supra note 4, at 386. See also Seth Kreimer, Does Pro-Choice Mean ProKevorkian?: An Essay on Roe, Casey and the Right to Die, 44 AM. U. L. REV. 803, 807 (1995). As Kreimer explains:

Assisted suicide presents our society with a fearsome dilemma. Forbidding [it] leaves some citizens with the prospect of being trapped in agony or indignity from which they could be delivered by a death they desire. But permitting [it] risks the unwilling or manipulated death of the most vulnerable members of society, and the erosion of the normative structure that encourages them, their families, and their doctors to choose life.

Id.

${ }^{\text {to }}$ See Arras, supra note 4 , at $386-87$. A case quite similar to the one suggested by Arras (and perhaps the very one he had in mind) occurred in Michigan. Ellen Ruth Ward, a 69-year-old woman, suffered from a persistent pelvic pain that forced her to stay in her home and led her to consider suicide. At first Medicare refused to cover the cost of an implantable pump that would bathe Ms. Wood's spinal column in morphine. But when a Detroit newspaper publicized Ms. Wood's desperate situation, 
It is easier to say this than to keep it in mind when one is confronted with what palliative care experts tell us is the rare case-the case where even the most sophisticated pain relief cannot alleviate pain." As Dr. Timothy Quill, one of the nation's most eloquent proponents of PAS, has remarked, what those opposed to the legalization of PAS portray as a "tradeoff" between the good of society generally and the "real suffering" of a relatively few individuals "radically changes focus" when you or someone you love is doing the suffering. ${ }^{12}$

\section{How Opponents of PAS TREAT THE "HARD CASES"}

What should be done about the compelling cases, those that seem to cry out for PAS/euthanasia? A close look at the writings of some of the most forceful and persuasive opponents of any legalization of PAS/euthanasia discloses that they are not really opposed to the practice in every case as much as they are to its legalization. Thus Ezekiel Emanuel readily concedes that in some cases, such as those where a patient must suffer despite all available palliative care, "physician-assisted suicide or euthanasia can offer obvious benefits-can end a life that is worse than death."13 However, Emanuel quickly adds:

But those cases distort the picture. The question is not about whether intervention is right for this or that particular patient. In any given case it may be the ethical thing to do, whatever the law says-and should be done. The question confronting the United States is one of policy: Should we broadly legalize physician-assisted suicide and euthanasia. ${ }^{14}$

Medicare changed its position. A delighted Ms. Wood announced that with the pump she could "get out and socialize with people." Although surgeons offered to waive their fees and the manufacturer of the pump offered to discuss its cost, it was reported that with hospital costs the operation would still come to about $\$ 14,000$. See Sharoney Andrews, Woman in Pain Gets OK for Pump, Detrorr FreE Press, Mar. 2, 1993, at 3A.

${ }^{11}$ See NEW YORK TASK FORCE REPORT, supra note 3, at 40 ("modern pain relief techniques can alleviate pain in all but extremely rare cases"). However, "a serious gap exists between what medicine can achieve and the palliative care routinely provided to most patients;" patients often fail to receive adequate pain relief even when effective treatments are available. $I d$. at 35.

${ }^{12}$ Timothy E. Quill, The Care of Last Resort, N.Y. Times, July 23, 1994, at 15. See also Timothy E. Quill \& Robert Brody, "You Promised Me I Wouldn't Die Like This!," 155 ARCHIVES INTERNAL MED. 1250-51 (1995) ("Our experience suggests that acceptable pain relief [for dying patients] can be achieved about $98 \%$ of the time, which is reassuring unless you are unfortunate enough to be among the unrelieved $2 \% . "$ ).

${ }^{13}$ Ezekiel Emanuel, Whose Right to Die?, ATLANTIC MONTHLY, Mar. 1997, at 73-78.

${ }^{14} I d$. (emphasis added). 
Another bioethicist opposed to the legalization of PAS/euthanasia, Mark Siegler, has similarly observed that although a compelling individual case for PAS/euthanasia "would not support the legalization of such a practice," it might constitute an exception to the general prohibition. ${ }^{15}$ However, warns Professor Siegler, physicians who provide suicide assistance in these compelling cases, "place themselves at legal risk-a kind of conscientious objection to prevailing norms." (Elsewhere, Professor Siegler has made it clear that he does not believe that physicians who provide suicide assistance in these exceptional cases put themselves at much legal risk. ${ }^{17}$ )

John Arras is still another commentator opposed to the legalization of PAS/euthanasia who is not unhappy about physicians engaging in these practices in exceptional cases. (Indeed, as we shall see, it seems that Professor Arras would be more unhappy if physicians did not perform PAS/euthanasia in compelling cases.) Thus Arras concluded a recent article with "a plea

${ }^{15}$ Mark Siegler, Is There a Role for Physician-Assisted Suicide in Cancer?: No, in IMPORTANT ADVANCES IN ONCOLOGY 281, 289 (V. DeVita et al. eds, 1996).

${ }^{16}$ Id. Physicians who provide suicide assistance in compelling cases are better described as "conscientious objectors" than as civil disobedients. "Civil disobedience" usually takes place publicly. Although physicians who provide suicide assistance may believe that there is an indefensible discrepancy between moral standards and the law-on-the-books, few are likely to protest this discrepancy by providing suicide assistance openly or publicly. See generally James F. Childress, Civil Disobedience, Conscientious Objection, and Evasive Noncompliance: A Framework for the Analysis and Assessment of Illegal Actions in Health Care, 10 J. MED. \& PHIL. 63, 66-69, 73 (1985).

${ }_{17}^{17}$ In a course of a televised debate with philosopher Margaret Battin, Professor Siegler remarked:

I don't think we should take the chance of legalizing assisted suicide and euthanasia ... to meet the needs of that small group [those suffering "bad" deaths despite the best efforts of health professionals]. [These patients] can often find appropriate care from physicians who are sympathetic to their needs. Those physicians, if they assisted such patients, have never been subjected in this country to prosecution. Prosecutors have used considerable discretion in acknowledging the rights of patients and doctors to reach certain agreements between themselves.

NewsHour with Jim Lehrer (PBS television broadcast, Apr. 8, 1996).

To be more precise, it seems that no American jury has ever convicted a physician of homicide for performing active voluntary euthanasia, but in the last half-century at least four physicians have been prosecuted for engaging in such an act. Interestingly, in two of the four cases the patient was a member of the doctor's family. See James A. Tulsky et al., $A$ Middle Ground on Physician-Assisted Suicide, 5 CAMBridge $Q$. HEALTHCARE ETHICS 33, 33-34 (1996). Apparently no physician has ever been prosecuted for prescribing pills in order to help a patient commit suicide. See Sidney H. Wanzer et al., The Physician's Responsibility Toward Hopelessly Ill Patients: A Second Look, 320 NEW ENG. J. MED. 844, 848 (1989). 
to maintain the legal status quo."18 And what did he mean by the "legal status quo"? To quote Arras, it is "a regime that does not legally sanction PAS and euthanasia, but nevertheless covertly permits some particularly compassionate and courageous physicians to violate the law in fear and trembling."19

I think it fair to say that Arras and other prominent opponents of PAS such as Professors Emanuel and Siegler are defending the flat prohibition against PAS partly on the ground that it is not really a flat ban-partly on the ground that "the availability of informal practice and informally agreed-upon 'rights," especially in the most compelling cases, reduces the pressure to legalize these practices formally. ${ }^{20}$ Four decades ago I took essentially the same position. ${ }^{21}$ Now I am a good deal less sure which way the "availability of informal practice" cuts.

Four decades ago, the focus was on active voluntary euthanasia, rather than PAS, and in those days the highly publicized cases usually involved a close relative who had "hastened the death" of a seriously ill person, not a physician. But in that era, too, there was a wide gap between the "law on the books" and the "law in action." 22

My response, some forty years ago, was to quote with approval from a then recent book by Charles Curtis, who stated his views on euthanasia as follows:

If the circumstances are so compelling that the defendant ought to violate the law, then they are compelling enough for the jury to violate their oaths. The law does well to declare these homicide unlawful. It does

${ }^{18}$ Arras, supra note 4, at 365.

${ }^{19} I d$. (emphasis added).

${ }^{20}$ Cf. Cass R. Sunstein, The Right to Die, 106 YALE L.J. 1123, 1130 (1997). Writing some months before the U.S. Supreme Court upheld state anti-assisted suicide laws in the Glucksberg and Quill cases, Professor Sunstein observed:

The content of law depends not merely on the statute books but also on prosecutorial practice, and it is safe to say that in many cases prosecutors do not and will not deviate their limited resources to the most benign cases of voluntary active euthanasia. The availability of informal practice and informally agreed-upon "rights" should relieve some of the pressure for a constitutional guarantee.... Id.

I hasten to add that although Sunstein maintained that the Supreme Court should not rule that laws forbidding PAS are unconstitutional, he did favor PAS as a matter of public policy. Id. at 1126. Nevertheless, Sunstein's "relieving some of the pressure" argument seems equally applicable whether the issue is formally legalizing PAS or whether it is constitutionally guaranteeing PAS.

${ }^{21}$ See Kamisar, supra note 8, at 970-72.

${ }^{22}$ Id. at $970-71$. 
equally well to put no more than the sanction of an oath in the way of an acquittal. $^{23}$

When all is said and done, Curtis may have been right. But four decades later I cannot help wondering whether the passage from his book that I quoted with approval is a much better example of stylish writing than of deep thinking. If I could do it over again, I would not so quickly dismiss the complaint that "public confidence in the administration of criminal justice is hardly strengthened when moral issues are shifted instead of being solved, or when the law relegates to juries the function of correcting its inequities." ${ }^{24}$

\section{ARE OPPONENTS OF PAS INSISTING ON STANDARDS THEY THEMSELVES COULD NOT (AND WOULD NOT) SATISFY?}

Perhaps Arras (and Emanuel, Siegler and others who balk at the legalization of PAS/euthanasia but find it acceptable in certain individual cases) should be commended for forthrightly admitting that should they ever suffer such a "terrible. fate" themselves (i.e., an unavoidably painful or degrading existence at the end of life), they "would hope to find a thoughtful, compassionate, and courageous physician to release them from their misery." ${ }^{25}$ Nevertheless, this concession is quite troubling.

In Regina v. Dudley $\mathcal{E}$ ' Stephens, the famous British "necessity" case, the court recognized that the defendants had been "subject to terrible temptation" and to "sufferings which might break down the bodily power of the strongest man and try the conscience of the best," defense to criminal homicide. The court took comfort in the notion that "[w]e are often compelled to set up standards we cannot reach ourselves, and to lay down rules which we could not ourselves satisfy." ${ }^{27}$ (Why? one might ask.) I have taught Dudley $\mathcal{E}^{\circ}$ Stephens many times-but never without voicing great uneasiness about establishing or preserving criminal laws that "we could not ourselves satisfy."

${ }^{23}$ CHARLES P. CURTIS, IT's Your LAW 95 (1954), quoted in id. at 971.

${ }^{24}$ Helen Silving, Euthanasia: A Study in Comparative Criminal Law, 103 U. PA. L. REV. 350, 354 (1954), quickly dismissed in Kamisar, supra note 8, at 973.

${ }^{25}$ Arras, supra note 4, at 368.

${ }^{26}$ Regina v. Dudley \& Stephens, 14 Q.B.D. 273, 279 (1884).

${ }^{27}$ Id. at 288. 
Yet Professor Arras and others opposed to the legalization of PAS/euthanasia seem to be saying just that. One would think that as a general proposition the criminal law "should correspond with the actual feelings of the community, right or wrong," 28 and that as another general proposition it would be wrong "to punish what would not be blameworthy in an average member of the community." ${ }^{29}$ How then may one take the position that we should continue to keep PAS/euthanasia criminal under all circumstances even though we think it likely and understandable that the average person will engage in such conduct in certain circumstances? Indeed, Arras and other opponents of PAS/euthanasia seem to go a step further. They seem to be saying that we should neither repeal nor revise criminal laws that people who are better than average-"compassionate, and courageous physicians"-hopefully will violate under certain circumstances.

The sympathy many opponents of PAS/euthanasia express for what they would say are the relatively few people who suffer an unavoidably agonizing death, and the ambivalence with which they view these hard cases while stoutly resisting any legalization of PAS/euthanasia, has not escaped the attention-or the displeasure-of their adversaries. A good example is Professor Sylvia Law's sharp response to some of the comments John Pickering made in expressing his opposition to PAS/euthanasia.

At the time he chaired the American Bar Association's Commission on Legal Problems of the Elderly, Pickering incurred strong criticism when, along the same lines as Arras and others, he distinguished between PAS/euthanasia as public policy and PAS/euthanasia as a response to the circumstances of an individual case. In leading the successful opposition to an attempt to have the ABA endorse proposals to legalize PAS, Pickering expressed agreement with the New York Task Force Report that PAS/euthanasia is "unwise public policy" and that "it poses great danger to the most vulnerable segments of our society-the elderly, the poor and the persons with disabili-

${ }^{23}$ Oliver Wendell Holmes, The Common LAW 36 (Mark Howe ed., 1963).

${ }^{29} I d$ at 62 ("[T] the community would be to enforce a standard which was indefensible theoretically, and which practically was too high for that community."). 
ties." But then he added: "At the same time I selfishly reserve my right to do in private what my family, my doctor and pastor and $\mathrm{I}$, in loving consultation, voluntarily agree is best." ${ }^{\text {"31 }}$ Sylvia Law, a strong proponent of PAS, responded: "While [Mr. Pickering's] candor is refreshing, it may be wise to enact legal principles that are applicable to all. Formal rules, justified to protect the vulnerable and then ignored by the powerful, are apt to be unfair to all, and most especially to those they purport to protect." 32

Professor Law's criticism deserves a response and that is the focus of the next section.

\section{How MEANINGFUl WILl THE SAFEguARDS CONTAINED IN LAWS AUTHORIZING PAS TURN OUT TO BE IN PRACTICE?}

One may put the matter quite differently: Fortunately for Mr. Pickering, if laws were passed authorizing and regulating PAS/euthanasia, he and well-to-do people like him would be in a position to avail themselves of the safeguards such laws are likely to contain; unfortunately, many members of our society (and not just the most vulnerable ones) would not be.

Professor Law speaks of "legal principles that are applicable to all." But here, as elsewhere, rules of general applicability may affect different people very differently. In the criminal justice area, for example, various rules often affect the poor more harshly than they do the rich. ${ }^{33}$ As is well known, the Supreme Court addressed this problem in Gideon $v$. Wainwright $t^{34}$ and many other cases. ${ }^{35}$ Unlike the criminal justice area, however, the government is under no constitutional obligation to minimize the influence of poverty or poor economic circumstances

${ }^{30}$ John H. Pickering, The Continuing Debate over Active Euthanasia, A.B.A. BroETHICS BulI., Summer 1994, at 1, 15.

${ }^{31} I d$.

${ }^{32}$ Sylvia Law, Physician-Assisted Death: An Essay on Constitutional Rights and Remedies, 55 MD. L. Rev. 292, 314 (1996).

ss See Douglas v. California, 372 U.S. 353, 361-62 (1963) (Harlan, J., dissenting).

" 372 U.S. 335 (1963).

${ }^{35}$ See, e.g., Ake v. Oklahoma, 470 U.S. 68 (1985); Douglas, 372 U.S. at 353; Griffin v. Illinois, 351 U.S. 12 (1956). See generally ATTORNEY GENERAL's COMM. ON POVERTY AND THE ADMINISTRATION OF CRIMINAL JUSTICE, POVERTY AND THE ADMINISTRATION OF FEDERAL CRIMINAL JUSTICE (1963) (often called "the Allen Committee" after its chair, Prof. Francis A. Allen). The committee was appointed by then-Attorney General Robert F. Kennedy. 
on the administration of the laws governing physician-assisted death. ${ }^{36}$

It is all very well to point out that because "the differentiation of major depression from normal responses to serious illness is a highly specialized and difficult clinical task for which few nonpsychiatric clinicians are adequately prepared," ${ }^{37} \mathrm{pa}-$ tients who ask for a physician's assistance in committing suicide should be seen by a psychiatrist. ${ }^{38}$ But who will pay for the psychiatrist's services?

It is all very well to emphasize that "independent and impartial oversight by a certified palliative-care consultant is a vital safeguard in [a] proposed policy of legalized physician-assisted death"39 and that, if necessary, these consultants should be able

${ }^{36}$ Nor would any legislature be likely to do so. As noted in Washington v. Glucksberg, 117 S. Ct. 2258, 2266 (1997), two months before the Court handed down its decisions in the much-awaited PAS cases, President Clinton signed the Federal Assisted Suicide Funding Restriction Act of 1997, prohibiting the use of federal funds in support of PAS. See id. at 2259, 2266.

${ }^{37}$ Susan D. Block \& J. Andrew Billings, Patient Requests to Hasten Deaths, 154 ARCHIVES INTERNAI MED. 2039, 2044 (1994). See also Herbert Hendin, Suicide and the Request for Assisted Suicide: Meaning and Motivation, 35 DuQ. L. REv. 285, $287-88$ (1996); Ann Alpers \& Bernard Lo, Physician-Assisted Suicide in Oregon: A Bold Experiment, 274 JAMA 483, 484 (1995); Nathan Cherny et al., The Treatment of Suffering When Patients Request Elective Death, 10 J. Palliative CARE 71, 73 (1994); Guy Benrubi, Sounding Board: Euthanasia-The Needs for Procedural Safeguards, 326 JAMA 197, 198 (1992); David C. Clark, "Rational" Suicide and People with Terminal Conditions or Disabilities, 8 IsSUES L. \& MED. 147, 155 (1992); Yeates Conwell \& Eric D. Caine, Rational Suicide and the Right to Die, 325 NEw ENG. J. MED. 110, 111 (1991).

${ }^{33}$ See Block \& Billings, supra note 37, at 2044. However, despite "a well-known and strong association between depression and suicide, especially for patients with cancer," the Oregon Death with Dignity Act, the first act to legalize PAS in the United States, does not require a psychiatric evaluation of patients who request PAS; it only recommends such an evaluation if the patient's physician suspects mental illness. See Ezekiel J. Emanuel \& Elisabeth Daniels, Oregon's Physician-Assisted Suicide Law: Provisions and Problems, 156 ARCHIVEs INTERNAL MED. 825, 827-28 (1996).

${ }^{39}$ Franklin G. Miller et al., Sounding Board: Regulating Physician-Assisted Death, 331 NEw ENG. J. MEd. 119, 121 (1994) [hereinafter Miller et al., Sounding Board]. See also Franklin G. Miller et al., Can Physician-Assisted Suicide Be Regulated Effectively?, 24 J.L. MED. \& ETHICs 225, 226 (1996) ("the most important safeguard" is consultation with an independent palliative care expert who, inter alia, would verify that "the request for hastened death is not driven by a treatable depression, inadequate pain relief, or lack of support."). Consider, too, Christopher James Ryan \& Miranda Kaye, Sounding Board: Euthanasia in Australia-The Northern Territory Rights of the Terminally Ill Act, 334 NEw ENG. J. MED. 326, 327 (1996):

The Act places a strong emphasis on palliative care. Assistance [in committing suicide] is warranted only when the best palliative care has not succeeded in relieving the pain, suffering, or distress of a terminally ill patient. Euthanasia [or, I would add, PAS] can never be divorced from the issue of whether palliative care 
to obtain the services of additional experts to ascertain the patient's competence or medical condition or the adequacy of her palliative care. ${ }^{40}$ But once again, who will pay for these services? And who will pay for more effective palliative measures if existing measures are deemed to fall short?

We should keep in mind that the United States is one of the very few industrialized nations in the world which lacks a system of national health insurance or national health care. ${ }^{41}$ Thus the financial aspects of death and dying loom large in this country and the situation is grim:

Over 34 million people in the United States have no health insurance and an additional 80 million people are estimated to be significantly "underinsured" if faced with a serious or chronic illness .... The elderly and minority populations are hardest hit by the constraints of a failing health-care reimbursement system.

The uninsured and underinsured have limited access to the least expensive modality of pain relief, such as oral analgesics, but are excluded from more recent advances in pain treatment, such as PCA pumps, intraspinal analgesics, and other more expensive modalities. ${ }^{42}$

has been adequate, and this emphasis addresses the concern that euthanasia might become an alternative to palliative care.

${ }^{10}$ See Miller et al., Sounding Board, supra note 39, at 121.

"See Margaret Battin, Euthanasia: The Way We Do It, The Way They Do It, 6 J. PAIN \& SYMPTOM MGMT. 298, 304 (1991). Apparently the only other exception among industrialized nations is South Africa. In sharp contrast to the United States, in the Netherlands, where PAS/euthanasia is legally tolerated,

[a]lmost all patients $(99.4 \%$ ) have healthcare insurance and $100 \%$ of the population is insured for the cost of protracted illness. There are no financial incentives for hospitals, physicians, or family members to stop the care for patients. Moreover, the legal right of the patient to healthcare on the basis of his insurance will override budget and other financial agreements.

R.J.M. Dillman, Euthanasia in the Netherlands: The Role of the Dutch Medical Profession, 5 CAMBRIDGE Q. HEALTHCARE ETHICs 100, 105 (1996).

${ }^{42}$ Betty R. Ferrell \& Hurdis Griffith, Cost Issues Related to Pain Management: Report from the Cancer Pain Panel of the Agency for Health Care Policy and Research, $9 \mathrm{~J}$. PAIN \& SYMPTOM MGMT. 210, 232 (1994). Elsewhere, the authors state that the monthly cost of PCA morphine at home is about $\$ 4,000$ per month. Id. at 226. See also Council on Scientific Affairs, AMA, Good Care of the Dying Patient, 275 JAMA 474, 476 (1996); Arras, supra note 4, at 372; Battin, supra note 41, at 304.

Consider, too, the "managed care" context in which legalized PAS would occur. "Over sixty million Americans receive care through health maintenance organizations (HMOs)," and HMOs are only one kind of managed care organization. Susan M. Wolf, Physician-Assisted Suicide is the Context of Managed Care, 35 DuQ. L. REv. 455, 45556 (1996). "An emerging literature expresses considerable anxiety" about how "costcontainment efforts and other features of managed care would affect the use of assisted suicide if it were legalized." Id. at 456; see also id. at 456-57 (citing authorities). Professor Wolf's own article is an addition to that "emerging literature." She observes: 
Those favoring the legalization of PAS/euthanasia may be irked by the fact that Pickering and other opponents do not rule out these practices as possible options for themselves, but this stance underscores "the distinction between the morality of individual acts and the wisdom of social policy."

No doubt Mr. Pickering's doctors are well trained to detect depression (and anything else), but I think he may properly resist the legalization of PAS/euthanasia on the ground that "the majority of individuals who kill themselves suffer from depression that is treatable with appropriate clinical care," yet "too often, clinicians fail to detect treatable depression or other psychiatric illness, assuming that the depression is expected or beyond treatment," and "most doctors are not adequately trained to diagnose depression especially in complex cases such as patients who are terminally ill."

No doubt Mr. Pickering's doctors will provide the most effective and sophisticated palliative care available, but I think he may properly resist the legalization of PAS/euthanasia on the ground that there is good reason to believe that "current medical practice radically undertreats pain, making suicide a more attractive option than is technologically necessary"-and "the poor and isolated who have the least leverage in seeking relief from the medical system will be particularly subject to this danger." 45

The case of the dying person who requests PAS because of unbearable suffering which derives largely from her poor economic circumstances presents a terrible dilemma. One may argue that to allow physicians to perform PAS/euthanasia in such cases would be to "make them accomplices with society's refusal to care for its dying members." deny patients PAS in such cases is not to avoid "complicity" with

Under the incentives in a fee-for service system, physicians profit by offering patients treatment for their illness, interventions for their depression, pain relief, and encouragement to go on with life if possible. Under managed care incentives, physicians and organizations lose money by doing all of these things and profit instead by encouraging patients considering assisted suicide to go ahead with the practice.

Id. at 473 .

\footnotetext{
${ }^{43}$ Arras, supra note 4, at 373.

${ }^{14}$ NEW YORK TASK FORCE REPORT, supra note 3, at 126-27.

${ }^{45}$ Kreimer, supra note 9, at 827.

${ }^{46}$ See Alpers \& Lo, supra note 37, at 485 (recognizing both horns of the dilemma).
} 
societal inequalities, but to magnify such inequalities ${ }^{47}$-and conclude, albeit with great sadness, that PAS is "the least bad option" for such socially disadvantaged patients. ${ }^{48}$

The dilemma presented by these cases is not easily resolvable. But I would emphasize a point made very recently by a distinguished Committee on Care at the End of Life: offering patients suffering from avoidable pain and other symptoms "just two options-either physician assistance for hastened death or continued life with untreated pain-is a highly constricted choice that undermines the principle of autonomy." ${ }^{49}$

\section{How the LEgAIIZATION OF PAS IS LIKELY TO AFFECT THE DYNAMICS OF DEATH AND DYING}

The enactment of a statute authorizing and regulating PAS/euthanasia raises problems that are likely to escape attention when the issue is debated in terms of what would be desirable in a dramatic, individual (and relatively rare) case. For example, in the compelling case typically presented by proponents of PAS/euthanasia, and often dwelt on by the media, the request for active intervention to bring about death, and the ensuing conversation with the physician, are patient-initiated. This is likely to change (indeed, would probably have to change

${ }^{47}$ See COMmitTe on CARE AT THE END OF LIFE, APPROACHING DEATH: IMPROVING CARE AT THE END OF LIFE 205 (Marilyn J. Field \& Christine K. Cassel eds., 1997) [hereinafter APPROACHING DEATH], a report which recognizes both horns of the dilemma. See also the thoughtful discussion in Franklin G. Miller et al., Can Physician-Assisted Suicide Be Regulated Effectively?, 24 J.L. MED. \& ETHICs 225, 230 (1996).

${ }^{43}$ See Alpers \& Lo, supra note 37, at 485.

${ }^{49}$ APPROACHING DEATH, supra note 47, at 205; see also id. at 270-71. The solution suggested by Franklin Miller, Howard Brody and Timothy Quill when poor or socially disadvantaged dying patients request PAS to end their avoidable pain is for their physicians to "seek emergency help in marshalling resources for such patients so they can make use of standard palliative care to alleviate their terminal suffering." Miller et al., supra note 47, at 230. But I do not think this would work. Assuming arguendo that it would, how could we decline to "seek emergency help" for other socially disadvantaged, terminally ill patients, i.e., those who are also suffering much pain because they lack adequate financial resources but do not request PAS/euthanasia? Would the only way for such patients to trigger efforts to obtain effective palliative care for their terminal suffering be to request PAS/euthanasia? If (as I think unlikely) this proved to be effective, and word spread, would all socially disadvantaged, terminally ill patients then request PAS in order to maximize their chances of obtaining effective palliative care (if only to revoke their requests when such care became available)? 
if these practices become lawful "medical treatment" options). ${ }^{50}$ As the New York Task Force has pointed out:

As with other "treatments," judgments about when and for whom assisted suicide and euthanasia are provided would be managed principally by physicians, not their patients. ... Patients bring [a state of vulnerability caused by serious illness] to their relationship with physicians. Physicians in turn hold the knowledge and expertise patients may desperately need, adding to the profound dependence that characterizes the doctorpatient relationship....

If assisted suicide and euthanasia were accepted as "therapy," physicians would make a medical judgment about which patients are "good" candidates for the practices. Physicians would also do what is routinely called for in good medical practices-they would make a recommendation. [And these] recommendations would be a powerful factor in their patients' choices. Indeed, patients generally do what their doctors recommend. ${ }^{51}$

More generally, the legalization of PAS/euthanasia for certain patients would change the way these patients and those around them would view their lives-and the "hastening" of their deaths. $^{52}$

The legalization of PAS/euthanasia might lead many to regard "eligible" patients who decline to pursue these options as "responsible for their own suffering." "53 After all, it might be argued, once PAS/euthanasia becomes a lawful alternative, if a patient declines a lethal injection or a lethal dose of barbiturates, does not her continued pain and suffering become her own decision and her own responsibility ? $^{54}$

Moreover, the availability of PAS/euthanasia, a lawful and therefore reasonable option under certain circumstances, would

${ }^{30}$ The Oregon act, the first to legalize PAS in the United States, does not prohibit physicians from being the first to bring up the subject of PAS with eligible patients. See Alpers \& Lo, supra note 37, at 485; Emanuel \& Daniels, supra note 38, at 827. I think it noteworthy that "more than half of Dutch physicians consider it appropriate to introduce the subject of euthanasia to their patients." Herbert Hendin, The Slippery Slope: The Dutch Example, 35 DuQ. L. REv. 427, 428 (1996).

${ }^{51}$ NEW YORK TASK FORCE REPORT, supra note 3, at 121-22. See also Hendin, supra note 37 , at 304 (discussing the vulnerability and dependency on others of terminally or seriously ill patients).

${ }^{52}$ See NEW YORK TASK FORCE REPORT, supra note 3, at 95.

${ }^{53}$ See Emanuel, supra note 13, at 79.

${ }^{54}$ See id. "Placing the blame on the patient," adds Professor Emanuel, "would reduce the motivation of caregivers to provide the extra care that might be required, and would ease guilt if the care fell short. Such an easy, thoughtless shift of responsibility is probably what makes most hospice workers so deeply opposed to physicianassisted suicide and euthanasia." Id. 
deny eligible candidates "the possibility of staying alive by default. ${ }^{, 55}$ As one commentator has observed:

When someone shows impatience or displeasure with us, we jokingly say "Well, excuse me for living!" But imagine that it were no joke; imagine that living were something for which one might reasonably be thought to need an excuse....

Unfortunately, our culture is extremely hostile to any attempt at justifying an existence of passivity and dependence. The burden of proof will lie heavily on the patient who thinks that his terminal illness or chronic disability is not a sufficient reason for dying.

What is worse, family members and others to whom a patient wants to justify his choices, are often in a position to incur severe financial and emotional costs from any prolongation of his life. Many of the reasons in favor of his death are likely to be exquisitely salient in their minds. I believe that some of these people may actively pressure the patient to exercise the option of dying. (Students who hear me say this usually object that no one would ever do such a thing. My reply is that no one would ever do such a thing as abuse his own children or parents-except that many people do.) ${ }^{56}$

If, as one sociologist has pointed out, suicidal persons are already "succumbing to what they experience as an overpowering and unrelenting coercion in their environment to cease living, ${ }^{, 57}$ are not these pressures likely to increase in a society that sanctions assisted suicide? In a society which recognizes by specific legislation that assisted suicide (and hence suicide as well) is a rational and reasonable course of action in certain circumstances, and a society in which assisted suicide will not only be thinkable but speakable, will it be or become the "right" thing to do under certain circumstances? The courageous thing? The disappointing or selfish or cowardly thing not to do $?^{58}$

Are these the kind of questions we want a gravely ill person to ponder? Are these the kind of pressures we want to exert on a very sick person $?^{59}$ I think the point is well made in, of all places, a letter to the editor:

To say that people will still be free to say "no" to assisted suicide [if and when such a practice is legalized] is not enough. The state has no right to put seriously ill, diseased, handicapped, dying people under the burden of having to make such a decision.

${ }^{55} \mathrm{~J}$. David Velleman, Against the Right to Die, 17 J. MED. \& PHIL. 665, 673 (1992).

${ }^{56}$ See id. at 67475 .

${ }^{37}$ GeORge Colt, The EnIGMa of SuIcide 342 (1991) (quoting Menno Boldt) ("This sense of coercion takes many familiar forms: fear, isolation, abuse, uselessness, and so on.").

${ }^{\text {ss }}$ Cf. Donald L. Beschle, Autonomous Decisionmaking and Social Choice: Examining the "Right to Die,"77 KY. L.J. 319, 355 (1988-89).

${ }^{5}$ See Kamisar, supra note 8, at 990-93. 
I prefer to die without being able to ask for a doctor to help me kill myself. Come the time, I will not even want to think about that. I surely will not want the people around me thinking I should be thinking about that. ${ }^{60}$

\section{Is THERE A "MidDLE GROUND" ON PAS?}

If, for the reasons discussed above, it is undesirable to enact legislation authorizing PAS/euthanasia (even in very limited circumstances), is there a way to countenance the genuinely compelling cases-the heartwrenching cases that seem to cry out for PAS/euthanasia - without passing laws formally authorizing these practices? In other words, is there a "middle ground" on PAS/euthanasia ${ }^{61}$ - a way of tolerating the relatively few cases that generate great sympathy without condoning the generality of cases and without declaring, as formal legalization would, society's approval of the practice?

One of the nation's most formidable opponents of PAS/euthanasia, Ezekiel Emanuel, would answer in the affirmative. He urges us to establish a social policy that (a) keeps PAS/euthanasia illegal, thereby rejecting the view that a patient has a right to such procedures, but (b) recognizes that "in exceptional cases interventions are appropriate, as acts of desperation when all other elements of treatment-all medications, surgical procedures, psychotherapy, spiritual care, and so onhave been tried." ${ }^{62}$

${ }^{60}$ Julius B. Poppinga, Letter to the Editor, N.Y. TIMEs, June 13, 1994, at A6. Nan McColloch, a woman suffering from multiple sclerosis, wrote an op-ed piece conveying her experiences. See Nan McCulloch, Editorial, Assisted Suicide Is Permission to Kill, DETROIT FREE PRESS, Mar. 25, 1994, at 13A:

A law that would allow someone to help another person kill himself or herself scares me. Such a law is directed at me personally.

There already are enormous pressures on certain people that will only grow if we legalize assisted suicide. ...

I want to be free to live out my natural life even if I were useless, even if I were to cost the state an arm and a leg through hospitalization costs and Social Security disability payments....

My rights are threatened by the legalization of assisted suicide far more than [the rights of a seriously ill person who favors PAS is threatened] by the illegalization of it. She already is free to kill herself. ...

[I] am put in the position of defending my choice to live. I, more than she, must fear my final days at everyone else's mercy, since the road to hell is paved with merciful acts and good intentions.

${ }^{61}$ See Tulsky et al., supra note 17 , at 33 .

${ }^{62}$ Emanuel, supra note 13, at 79. As discussed earlier, see supra text accompanying notes 33-45, and as Professor Emanuel is well aware, many seriously ill Americans lack 
Unfortunately, Professor Emanuel does not spell out how society should go about both condemning PAS/euthanasia as a general matter and recognizing exceptions in truly compelling cases. I think the best reading of his article is that he would maintain the legal status quo-and its wide gap between "the law on the books" and the "law in action." "63

Although, like Emanuel, Howard Brody would not grant physicians the protection afforded by laws explicitly authorizing PAS/euthanasia, he, too, would accommodate those who engage in these practices in exceptionally compelling cases. ${ }^{64}$ But Professor Brody would not depend on the prosecutor's discretion or jury nullification. He would go a step further. According to Brody, when a compelling case arises (one where all medical interventions have failed to achieve a "good death" and the patient has voluntarily requested a physician-assisted death), and a physician carries out the patient's request and is then charged with criminal homicide or assisting in a suicide, the physician should be able to mount a defense to these charges, a defense called "a compassionate response to a medical failure."

I do not believe that a generally worded defense to criminal charges-such as "act[ing] compassionately and competently in assisting a death, by ensuring that a voluntary choice was made and that all other options for relief had been tried" change things very much, if at all. Unless physicians are told in advance what specific steps they should take to obviate any significant risk of a criminal prosecution, those physicians who currently balk at providing assistance in committing suicide are unlikely to become more venturesome and those physicians who now provide such assistance in secret are unlikely to do so in the open. 67

the financial resources to "try everything" before obtaining assistance in committing suicide. How should we deal with them?

${ }^{6 s}$ See supra notes 17-25 and accompanying text.

${ }^{64}$ See Howard Brody, Assisted Death-A Compassionate Response to A Medical Failure, 327 N. ENG. J. MED. 1384 (1992). Professor Brody does not believe that a statute could be drafted that "would list all possible justifications and restrictions in advance" and that the morality of assisting a patient's death is best determined "on the merits of the specific case." Id. at $1385,1387$.

${ }^{65} \mathrm{Id}$. at 1384 .

${ }^{66} I d$ at 1387.

${ }^{67}$ Cf. Charles H. Baron et al., A Model State Act to Authorize and Regulate PhysicianAssisted Suicide, 33 HARV. J. ON LEGIS. 1, 8-13 (1996). 
This problem has not escaped Dr. Brody's attention. He suggests a scheme whereby (a) arbitration boards sometimes used to handle malpractice claims would review PAS cases, and (b) the prosecutor's decision whether or not to charge a particular physician with a crime would be influenced by the conclusion reached by the board, i.e., a determination by the board that the physician had a valid defense would lead the prosecution to drop the matter. " "This legal framework," adds Brody, "might be supplemented by intraprofessional review" whereby physicians who have assisted in a patient's suicide "should be called on to defend their actions against the sharpest questioning of their peers, in an open forum." ${ }^{69}$

Brody's goal is a laudable one-protecting physicians who help their patients commit suicide in exceptionally compelling cases without formally endorsing PAS-but I do not think his scheme will work. I fail to see why prosecutors would surrender to arbitration boards a big chunk of their precious discretion to prosecute. Nor do I see why the prospect of appearing before an arbitration board, to say nothing of being subjected to "the sharpest questioning of [one's] peers," would not deter a physician from performing PAS/euthanasia even if she might otherwise have no objection to it. ${ }^{70}$

In effect, Dr. Brody is asking, and expecting, courageous (or foolhardy) physicians to step forward and contribute to the caseby-case development of the "common law" of "acting compassionately and competently in assisting a death" by putting their careers and reputations on the line. I think very few physicians, if any, would accommodate him.

James Tulsky, Ann Alpers and Bernard Lo are also searching for a "middle ground" on PAS." They, too, balk at "formally legalizing assisted suicide" because such a development would "declare society's approval of the practice." And under certain circumstances they, like Professor Brody, would make PAS an af-

\footnotetext{
${ }^{69}$ Brody, supra note 64, at 1387.

${ }^{69} \mathrm{Id}$.

${ }^{70}$ Moreover, I doubt that any competent lawyer would permit her client to be subjected to the "sharpest questioning" of her colleagues about her participation in a patient's suicide. Even aside from the possibility of a criminal prosecution, the risks are considerable: bad publicity; liability for wrongful death and medical malpractice; professional sanctions; and loss of hospital staff privileges.

${ }^{71}$ See Tulsky et al., supra note 17 .

${ }^{72} I d$. at 35 .
} 
firmative defense to criminal charges. But they are a good deal more specific. Under their proposal, PAS would remain a crime, but the act would not be punishable if the defendant physician proved by clear and convincing evidence that the suicidal patient was (a) a competent individual who was terminally ill, (b) suffering physical distress despite aggressive palliative care, and (c) the request for suicide was voluntary. ${ }^{73}$

To provide sufficient evidence that all the elements of the affirmative defense were satisfied, Tulsky, Alpers and Lo recommend, and contemplate, that the physician providing suicide assistance would discuss the case with colleagues and other professionals to assure that the patient is competent, that she is terminally ill, that her request for assisted suicide is stable and firm, that she is not suffering from a treatable depression and that her physical distress cannot be relieved by aggressive palliative care. ${ }^{74}$ However, a physician otherwise willing to provide suicide assistance is unlikely to consult freely with various specialists or otherwise perform PAS "in the open" unless convinced that she has proceeded so carefully and built such a strong defense against potential criminal charges that the possibility of being prosecuted is almost zero. Moreover, the various specialists contacted by such a physician are unlikely to want to "get

${ }^{73} I d$ at 38-39. At one point, the authors note that the defense would not be limited to physicians: Family members and close friends, too, could avail themselves of this defense (although a physician would have to be involved to make the necessary evaluation). Id. at 40 . However, I put this aside for purposes of the present discussion.

Forty years ago, Glanville Williams, an eminent British legal commentator, also proposed that the criminal law be amended to protect physicians who perform active voluntary euthanasia. However, unlike the Tulsky-Alpers-Lo formula, Williams's proposal was heavily tilted in favor of the physician:

[The amendment] would provide that no medical practitioners should be guilty of an offense in respect of an act done intentionally to accelerate the death of a patient who is seriously ill, unless it is proved that the act was not done in good faith with the consent of the patient and for the purpose of saving him from severe pain in an illness believed to be of an incurable and fatal character.

Glanville llewelyn Williams, The Sanctity of Life and the Criminal Law 340 (1957). "Under this formula," explained Williams, "it would be for the physician, if charged, to show that the patient was seriously ill, but for the prosecution to prove that the physician acted from some motive other than the humanitarian one allowed to him by law." Id.

${ }^{74}$ See Tulsky et al., supra note 17 , at 39 . 
involved" in the case unless they, too, are convinced that the chance of anyone being prosecuted is quite small. ${ }^{75}$

If the criminal law were amended as proposed by Tulsky, Alpers and Lo, what would be the best way for a physician willing to provide suicide assistance to proceed? I think the safest course would be to satisfy the conditions and follow the procedures set forth in the Model State $\mathrm{Act}^{76}$ (or some other proposed legislation)-conditions and procedures a group of experts deem necessary to provide a patient with adequate protection. $^{77}$

For example, in an effort to balance "the prevention of hasty decisionmaking against the prolonging of unbearable suffering," ${ }^{78}$ the Model State Act requires that the request for suicide assistance be in writing and that it be made on at least two occasions that are at least two weeks apart. ${ }^{79}$ Moreover, in order to assure that the patient's decision is "fully informed, free of undue influence, and not distorted by depression," ${ }^{, 80}$ the Act mandates that a professional mental health care provider evaluate the patient. ${ }^{81}$

A responsible physician can hardly be expected to do any more than satisfy the procedures contained in an Act drafted by nine highly regarded experts in law, medicine and ethics. On the other hand, a failure to comply with the provisions of the Act might give a prosecutor an opening. (I can almost hear the prosecutor now, maintaining that the physician should be indicted (and then convicted) because he or she was too arrogant

${ }^{75}$ Cf. Wanzer et al., supra note 17 , at 848 .

${ }^{76}$ See Baron et al., supra note 67.

$\pi$ Tulsky, Alpers and Lo suggest some implementing rules or guidelines of their own. For example, "in discussing how to go about establishing the "voluntariness" of a request for suicide assistance they comment:

A combination of facts will ordinarily suffice to establish voluntariness: the patient requested assistance with suicide on more than one occasion over a period of time; the defendant had an ongoing relationship with the patient; and the patient had been evaluated for depression, received counseling, or had explored alternatives to suicide.

Tulsky et al., supra note 17 , at 39 .

${ }^{78}$ Baron et al., supra note 67 , at 18.

${ }^{79}$ See id.

${ }^{80} \mathrm{Id}$.

${ }^{81}$ For purposes of the present discussion, I put aside the question of who will pay for the services of such an expert if the patient is uninsured and lacks adequate financial resources. 
or uncaring or incompetent to protect a terminally ill patient in the manner deemed essential by nine experts.)

Tulsky, Alpers and Lo should be commended for trying hard to achieve a "middle ground." But I venture to say that in the real world their plan would wind up at one end or the other, not in "the middle."

As discussed earlier, unless specific and detailed procedures and conditions were developed which, if followed, would almost guarantee that a physician would not be prosecuted, PAS/ euthanasia would continue to be performed in secret (or not at all). But there is another, and a very different, possible outcome. Suppose the courts or the medical profession adopted the specific provisions of the Model Act (or the new Oregon law legalizing PAS) as a way of implementing Tulsky, Alpers and Lo's affirmative defense. Or suppose rules or guidelines implementing the defense were developed over the years by the courts and/or the medical profession and/or the prosecutor's or the attorney general's office. Suppose further that these rules or guidelines became so detailed and so dominated the practice of death and dying that compliance with them virtually guaranteed immunity from prosecution. ${ }^{82}$ Then a significant number of physicians probably would practice PAS/euthanasia in the open-fully and freely consulting colleagues and other professionals and perhaps even ethics committees.

But this would no longer be a "middle ground." The willingness to perform PAS/euthanasia "in the open" would convey the message that the practice was now considered ethical. ${ }^{83}$ The

${ }^{82}$ Of course, this state of affairs would then resemble the situation in the Netherlands. Although euthanasia is technically illegal in the Netherlands, indeed still specifically prohibited by Article 293 of the Dutch Penal Code, the practice is "legally tolerated" if certain conditions are satisfied. Physicians who comply with a set of guidelines recognized by the courts and endorsed by the State Commission on Euthanasia are not subject to sanctions. See generally HERBERT HENDIN, SEDUCED BY Death: Doctors, Patients, and the Dutch Cure (1996); Carlos F. Gomez, REGULATING DEATH: EUTHANASIA AND THE CASE OF THE NETHERLANDS (1991); Battin, supra note 41, at 299; Maurice A.M. DeWachtler, Euthanasia in the Netherlands, 22 HASTINGS CTR. REP. 23 (1992); Dillman, supra note 41; John Keown, Euthanasia in the Netherlands: Sliding Down the Slippery Slope?, in EUTHANASIA EXAMINED: ETHICAL, Clinical and Legal Perspectives 261 (John Keown ed., 1995). Despite the continuing criminal prohibition against euthanasia, I believe that most people, both those inside the country and those outside, would say that under certain conditions euthanasia is "sanctioned" or "justified" or "approved" in the Netherlands.

${ }^{83}$ Compare the remarks of Professor Mark Siegler during a televised debate with Professor Margaret Battin, NewsHour with Jim Lehrer, supra note 17. At one point 
detailed rules or guidelines implementing the defense would have become the functional equivalent of a statute authorizing and approving PAS/euthanasia - the very result the authors of the proposal hoped to avoid.

\section{SOME FINAL REFLECTIONS}

As we have seen, some opponents of PAS/euthanasia defend the present regime partly on the ground that it covertly permits these practices to take place in the relatively few cases where such action is appropriate. ${ }^{84}$ But it is not at all clear which way this cuts. It may be contended that the availability of what might be called the underground practice of PAS/euthanasia reduces the pressure to legalize these acts, but it may also be argued that the current state of affairs results in "the worst of all worlds: unpopular laws stay on the books and are sporadically enforced against unwary defendants, but because of the prosecutor's need to avoid a jury, the crimes are not punished to the extent the legislature might think appropriate. $"{ }^{25}$

The American Law Institute's Model Penal Code has deservedly been called "the point of departure for criminal law scholarship." ${ }^{86}$ So I turned to the Code for help. But when I did so, different code provisions and commentaries seemed to point in different directions.

In rejecting the position taken by the Dudley $\mathcal{E}$ Stevens court $^{87}$ and other courts which have refused to recognize as de-

Siegler voiced strong opposition to legalizing PAS/euthanasia, maintaining, inter alia, that the small number of terminally ill patients who repeatedly request suicide assistance "can often find appropriate care from physicians who are sympathetic to their needs." Shortly thereafter, however, Siegler expressed unhappiness with the current state of affairs, where some PAS/euthanasia is practiced in secret. "If it were left to me," he added, "[agreements between physicians and patients to help patients commit suicide] ought to be regulated first by being looked at in advance by a committee of professionals and lay people ..., and secondly, it ought to be looked at retrospectively in a public arena ....." I venture to say that if Professor Siegler's suggestion were carried out society would in effect have "legalized" and "approved" PAS/euthanasia under certain conditions-a state of affairs Siegler has long resisted.

${ }^{84}$ See supra text accompanying notes 13-20.

${ }^{85}$ Andrew D. Leipold, Rethinking Jury Nullification, 82 VA. L. REv. 253, 301 (1996). At this point, Professor Leipold is not talking specifically about PAS/euthanasia but about the situation generally when a jury is permitted to nullify the law.

${ }^{86}$ Sanford H. Kadish, The Model Penal Code's Historical Antecedents, 19 RUTGERs L.J. 521,538 (1988).

${ }^{87}$ See supra text accompanying notes $26-27$. 
fenses to criminal homicide "necessity" (sometimes called "choice of evils") or "duress" (sometimes called "coercion"), the Reporters for the Model Penal Code explained:

[L] aw is ineffective in the deepest sense, indeed ... it is hypocritical, if it imposes on the actor who has the misfortune to confront a dilemmatic choice, a standard that his judges are not prepared to affirm that they should and could comply with if their turn to face the problem should arise. Condemnation in such a case is bound to be an ineffective threat; what is, however, more significant is that it is divorced from any moral base and is unjust. ${ }^{88}$

These are strong words and they seem to provide strong support for legalizing PAS/euthanasia-at least in those compelling individual cases where even some opposed to the legalization of PAS/euthanasia deem the acts appropriate. Yet, without carving out any exceptions for compelling cases, the Code elsewhere, to use its own description, "creates a separate offense of aiding or soliciting suicide," ${ }^{, 99}$ explaining:

The fact that penal sanctions will prove ineffective to deter [a suicidal individual from committing the act himself] does not mean that the criminal law is equally powerless to influence the behavior of those who would aid or induce another to take his own life. Moreover, in principle it would seem that the interests in the sanctity of life that are represented by the criminal homicide laws are threatened by one who expresses a willingness to participate in taking the life of another, even though the act may be accomplished with the consent, or at the request, of the suicide victim. ${ }^{90}$

The only concession the Model Penal Code is willing to make for heartwrenching cases is "to rely upon mitigation of sentence when the ground therefor appears." But this conces-

${ }^{83}$ MODEL PENAL CODE $\$ 2.09 \mathrm{cmt} .2$ at 7 (Tent. Draft No. 10 1960), in 1 MODEL PENAL Code AND CoMmentaries, $\$ 2.09$ at 372-75 (1985).

${ }^{89} 1$ MODEL PENAL CODE AND COMMENTARIES, supra note 88, $\$ 210.5$ at 100.

${ }^{90} I d$.

${ }^{91} I d$ at 102 . The commentary points out that $\S 210.5$ applies "only when the actor goes no further than aid or solicitation; if he is himself the agent of death, the crime is murder notwithstanding the consent or even the solicitation of the deceased." Id. at 106. However, the "homicide upon request" (i.e., active voluntary euthanasia) could be reduced to manslaughter if the act were done "in a state of extreme emotional distress." Id. Moreover, "there is power in the court to work an even larger mitigation under Section 6.12 or even to dismiss the charge under Section 2.12 in a really extreme case." Id.

Section 6.12 permits a judge, "having regard to the nature and circumstances of the crime and to the history and character of the defendant," to enter judgment of conviction for a lesser crime, and to sentence accordingly, if the judge "is of the view that it would be unduly harsh to sentence the offender in accordance with the Code." Id. Section 2.12, which deals with de minimis infractions, does not seem to apply at 
sion fails to mitigate the ordeal of a criminal prosecution or the stigma of a conviction. It is almost as if those who drafted the assisted suicide section and wrote the accompanying commentary were unaware of the sections dealing with "necessity" and "duress" and the commentary accompanying those provisions.

I do not deny it is hard to defend an absolute prohibition when you not only expect the prohibition to be violated in certain situations, but you can visualize circumstances where you would understand and forgive the person who did so. The best analogy I can think of is the absolute prohibition against torture. There, too, if we thought about it for a while, we could envisage some dramatic individual cases where there would be tremendous pressure to violate the prohibition, e.g., the "ticking bomb" case.

According to the press, a series of killings by terrorists has led the Israeli government to authorize harsh interrogation of suspected militants. The Israeli government has defended its decision by making what some have called the "ticking bomb" argument-underscoring the need to resort to torture to obtain information that could prevent imminent killings. ${ }^{92}$ But various human-rights groups in Israel remain unconvinced that a very few dramatic cases justify an exception to the absolute ban against torture. They fear that once a crack appears in the absolute prohibition, the crack will eventually widen - and that torture will start taking place under circumstances far removed from the "ticking bomb" case.

This may shock some people, but I believe that if a "ticking bomb" case actually arose in this country-i.e., the authorities had good cause to believe that a powerful bomb had been hidden in a huge office or government building and would explode in the next twenty-four hours and also had reason to believe that a person in their custody knew how, when and where this was to occur-the authorities would not shrink from using tor-

all. This section authorizes a court to dismiss a prosecution if, inter alia, the defendant's conduct actually caused or threatened the harm sought to be prevented "to an extent too trivial to warrant the condemnation of conviction" or "presents such other extenuations that it cannot reasonably be regraded as envisaged by the legislature in forbidding the offense." Id.

${ }^{92}$ See Joel Greenberg, Israel is Permitting Harsher Interrogation of Muslim Militants, N.Y. TIMES, Nov. 17, 1994, at A6; see also Joel Greenberg, Doctor Says Snapping of Head Killed Palestinian Held in Israel, N.Y. TIMES, May 1, 1995, at A6. 
ture. I also doubt (especially if the use of torture succeeded in preventing an imminent disaster) that most people would want the authorities to shrink from doing so.

For purposes of the present discussion, I need not answer the hard question of whether it should ever be permissible for law enforcement officials to resort to torture, e.g., to elicit information that would prevent a large explosion or some other calamity. I need only maintain that it is a very different question than whether we should enact a law formally sanctioning the use of torture in certain situations. It is much easier for the government to resort to torture in less-than-compelling situations when such methods are already formally permitted in some circumstances. On the other hand, by refusing to make any formal or official exceptions to the prohibition against torture, or by refusing to acknowledge that we should balance the costs and benefits of torture as a general matter, we strengthen the presumption against torture and maximize the likelihood that it will only be resorted to in the rarest and most compelling circumstances. $^{93}$

Here, as elsewhere, it is very hard to maintain absolute prohibitions. ${ }^{94}$ But here, as elsewhere, problems arise when one

${ }^{95}$ See the discussion in GuIdo CALABRESI, IDEALS, BELIEFS, ATTITUDES, AND THE LAW: Private LaW Perspectives on a Legal Problem 167 n.240 (1985), and Charles L. Black, Jr., Mr. Justice Black, the Supreme Court, and the Bill of Rights, HARPER's, Feb. 1961, at $63,67-68$. Both commentators discuss how we should go about deciding whether the police may torture a prisoner to get him to reveal the location of a nuclear bomb when the police know he has hidden the bomb somewhere in a major city and the bomb is due to explode in a very short time.

${ }^{9}$ Some may argue that the analogy to torture is not an apt one, because many more people support an absolute prohibition against torture than do an absolute ban against PAS/euthanasia and many more people believe that torture is inherently immoral than feel the same way about PAS/euthanasia. I hope we never have to test these propositions in the wake of a dozen terrorists bombings in Chicago, New York or Washington, D.C.

But consider this: In August, 1995, a terrorist blew up himself and four innocent passengers in a bus in the heart of Jerusalem. A few days later, Israeli authorities learned that Mr. Issa, the individual who had masterminded the suicidal bombing, had been taken into custody two days before the incident and was still in their custody. The chief of Israel's secret service then authorized the use of "moderate physical force," and Mr. Issa provided information that led to the arrest of 37 militants who had been planning additional bombings. The chief of Israel's secret service told the press that the blood of the next victims of terrorism would have been on his hands if physical pressure had not been used in the interrogation of Mr. Issa. And the Prime Minister added that had such pressure been applied earlier, the August, 1995, bus bombing might have been prevented. See Stephen Flatow, Israel's Fine Line, N.Y. TIMES, May 19, 1997, at A13. 
starts carving out exceptions. I venture to say that, however great the care with which one formulates the exceptions, "hard" cases are bound to emerge on the other side of the line and with it the pressure to extend the outer boundaries of the exceptions to embrace these new "hard" cases.

Twenty years ago, on the occasion of Professor Fred Inbau's retirement, I observed that - although happily Inbau never subscribed to this view-law professors "are supposed to be troubled and tentative, not take very strong and very clear positions on anything (except, perhaps, right down the middle)" ${ }^{\prime 5}$ and that-although happily Inbau also dissented from this view-many law professors believe that the way to enhance their status is "by showing how agonizingly subtle and complex an issue or a problem actually is, not by suggesting how simple it might really be."96

Of course, when I spoke of Inbau declining to take the conventional route, I had myself in mind as well. But I never promised, or at least I never meant to promise, that I could always show how simple seemingly subtle and complex problems really are. Sometimes, I am afraid, what appear to be agonizingly subtle and complex problems turn out to be just that."

Was torturing Mr. Issa immoral? A United Nations committee thinks so. But an American lawyer named Stephen Flatow does not. His daughter was killed in that August, 1995, suicide bombing. He thinks that foregoing the use of physical pressure when such interrogation methods can prevent the random murder of civilians is immoral. See id.

${ }^{95}$ Yale Kamisar, Fred E. Inbau: "The Importance of Being Guilty," 68 J. CRIM. L. \& CRIMINology 182 (1977), in Yale Kamisar, Police INTERRogation AND Confessions: ESSAYS IN LAW AND POLICY 95, 104 (1980).

${ }^{96} I d$. (emphasis in the original).

** Professor Inbau was in the audience for the Pope $E^{\circ}$ John Lecture on Professionalism. Professor Kamisar and Professor Inbau had dinner together (and talked about old times) following the Lecture. Professor Inbau passed away while this article was in page proofs. - Eds. 